\title{
Preservation effects of geniposidic acid on human keratinocytes (HaCaT) against UVB

Na Kyeong Lee

\begin{abstract}
Background: Geniposidic acid is a natural compound affiliated with iridoid glycoside which is contained in various plants such as Gardenia seeds, Eucommia bark, and Psyllium, and it is known that it has such effects as anti-inflammation, anti-virus, anti-cancer, anti-oxidation, suppression of stress, improvement of immune system, and relief of liver injury. However, there is a lack of research on action of geniposidic acid in dermal cells, so this research verifies effects of geniposidic acid on preservation of human keratinocytes, anti-oxidation, and DNA repair and finds out its mechanism.

Methods: This study demonstrated feasibility of geniposidic acid on cosmeceutical application via ultraviolet (UV) B-induced damage protective effects such as oxidative stress reduction, DNA repair, and decrease of apoptotic cell death. To investigate cytotoxicity of angelic acid and proliferation influence, researchers used formazan detection by water-soluble tetrazolium salts (WST). To examine cell cycle distribution and sub-G1 portion, fluorescence-activated cell sorting (FACS) analysis was used to the experiment. For further investigation, cleaved caspase-3 levels were determined in apoptotic cell death analysis. And we conducted comet assay, in vitro anti-oxidant effects using radical scavenging assay, lipid peroxidation analysis, and mRNA expression analysis.

Results: Geniposidic acid protects UVB-induced cytotoxic damage and reduces apoptotic cell death caused by UVB in human keratinocytes $(\mathrm{HaCaT})$. Also, this research finds out that geniposidic acid decreases formation of cleaved caspase-3 increase and reduces both tailed DNA and cyclobutane pyrimidine dimer (CPD) which is increased by UVB. Through radical scavenging assay, we demonstrate in vitro anti-oxidant effect of geniposidic acid and, via quantitative real-time polymerase chain reaction (qRT-PCR), find out that gene expression of superoxide dismutase 1 and 2 (SOD1 and SOD2) which are known as anti-oxidant gene increases dependently on concentration of geniposidic acid. Furthermore, geniposidic acid reduces lipid peroxidation to lead anti-oxidation effect. This research finds out that gene expression of XPC (XPC complex subunit, DNA damage recognition, and repair factor) and PCNA (proliferating cell nuclear antigen) which are DNA repair gene increases dependently on concentration of geniposidic acid.

Conclusions: Through this research, we verify that geniposidic acid has effects on anti-oxidation and DNA repair in human HaCaT damaged by UVB and suggest that geniposidic acid as a cosmetic material is fully worthy to use to delay dermal cellular senescence by UVB effectively.
\end{abstract}

Keywords: Geniposidic acid, HaCaT keratinocyte, Anti-oxidation, DNA repair, Ultraviolet B

\section{Background}

Dermal senescence is a complex phenomenon which is classified into intrinsic aging caused by the heredity and extrinsic aging through environmental exposure by UV (Jenkins 2002), and intrinsic aging is occurred by reactive oxygen species (ROS) which is formed in the course of cellular metabolism (Lee et al. 2012), and extrinsic

Correspondence: nklee2349@daum.net

JEl University, 808 Main Building, 178, Jaeneung-ro, Dong-gu, Incheon 22573, Republic of Korea aging occurs due to reactive oxygen which is formed by dermal permeation of UVB although there are several causes for extrinsic senescence (Kulms et al. 2002). Intracellular ROS causes damages on DNA and mitochondria and results in such intracellular damages as heterology in the course of energy metabolism as well as protein oxidation. The intracellular damages caused by oxidative stress occur cell cycle arrest, cellular senescence, and apoptosis which are shown on dermal keratinocyte to lead to dermal senescence (Cerella et al. 2009). DNA damage caused by 
UV activates ATM (ataxia-telangiectasia mutated) and ATR (ATM- and Rad3-related) proteins, which activate p53. When DNA gets damaged, activation of p53 which is a transcription factor induces expression of p21 to stop cell cycle and hinder cell growth (Smits and Medema 2001). So in this experiment, to examine preservation effect on $\mathrm{HaCaT}$ against UVB, as object, I selected geniposidic acid which is anti-cancer, anti-oxidation, and antiinflammatory properties.

Geniposidic acid as corresponding to $(1 S, 4 \mathrm{a}, 7 \mathrm{a} S)-1$ ( $\beta$ - $D$-glucopyranosyloxy)-7-(hydroxymethyl)-1,4a,5,7a-tet rahydrocyclopenta[c]pyran-4-carboxylic acid is a natural compound affiliated with iridoid glycoside which is contained in various plants such as Gardenia seeds, Eucommia bark, and Psyllium, and research on senescence-related insulin resistance improvement of genipin (Guan et al. 2013) and also research on airway inflammation and induction suppression of geniposide have been reported (Deng et al. 2013) with regard to biological action of Gardenia seeds. Also, the research on anti-oxidation and anti-inflammation action of manufactured Gardenia seeds and crocetin is known (Hong and Yang 2013). In the research on cancer cell proliferation suppression effect of Eucommia extract (Choi et al. 2003), geniposide and geniposidic acid were separated and refined respectively, and at the case of oral administration of these compounds, it significantly reduced tumor size of mouse in which cancer cell was transplanted (Hsu et al. 1997), and at in vitro experiment targeting C6 glioma cell, it induced apoptosis effectively (Chang et al. 2002). Also, in the experimental study depending on manufacturing of eucommia, as indicator substances, I selected geniposidic acid and geniposide which are mental stability factors in iridoid glycoside and examined its content depending on manufacturing, and through pharmacological experiment on catecholamine content within brain and plasma under the condition of pain, lipid metabolism, and restraint stress, it found out that it is significantly effective (Park and Kim 1992). Since the recent research trends on geniposidic acid, there has been a process of research on anti-cancer, anti-inflammation, and anti-oxidation, but nothing about research on application of geniposidic acid as cosmetic materials, and also, there have been no researches on mechanism in dermal cells. Also, researches on skin preservation against UV and about natural substances which delay cellular senescence have been increasing continuously in these days. So it is necessary to investigate various effects of geniposidic acid on usual action of keratinocyte in the course of dermal senescence. Therefore, this research intends to study effects of geniposidic acid such as cell preservation, anti-oxidation, and DNA repair and examine its effects to find out possibility for application of geniposidic acid as natural cosmetic materials which can help delaying dermal cellular senescence.

\section{Methods \\ Cell culture}

$\mathrm{HaCaT}$ cell line and $\mathrm{HaCaT}$ keratinocytes (ATCC, Manassas, VA, USA) were cultured using Dulbecco's modified Eagle's medium (DMEM; Hyclone, Logan, UT, USA) which contains $10 \%$ of fetal bovine serum (FBS; Hyclone) and $1 \%$ of penicillin/streptomycin (penicillin $100 \mathrm{IU} / \mathrm{mL}$, streptomycin $100 \mu \mathrm{g} / \mathrm{mL}$; Invitrogen/Life Techmologies, Carlsbad, CA, USA) for $\mathrm{HaCaT}$ culture and cultured it within cell incubator kept under the condition of $5 \%$ of $\mathrm{CO}_{2}$ with the temperature at $37^{\circ} \mathrm{C}$.

\section{Sample treatment}

I purchased geniposidic acid which is refined in the form of powder from Santa Cruz Biotech (Santa Cruz, CA, USA) and dissolved it in dimethyl sulfoxide (DMSO; Sigma-Aldrich, St. Louis, MO, USA) in a proper density to use it in the experiment. After I cultured $\mathrm{HaCaT}$ cell $\left(1 \times 10^{6}\right.$ cells/well $)$ in the cell medium for $24 \mathrm{~h}$, I added geniposidic acid in a proper density to culture medium and pretreated for $3 \mathrm{~h}$, and for ultraviolet $\mathrm{B}$ test on cells, I used UV-B lamp (UVP, Upland, CA, USA) to examine. I used fiber optic Spectrometer System USB2000 (Ocean Optics, Dunedin, FL, USA) to estimate UVB wavelength, and at the UVB test on $\mathrm{HaCaT}$, I washed it twice with phosphate-buffered saline (PBS; (Thermo Fisher Scientific, USA) in a $\mathrm{pH}$ of 7.4 to remove culture medium of cell culture dish. To prevent drying of cell, I opened cell culture dish lid for UVB test after adding $1 \mathrm{~mL}$ of PBS to cell culture dish, removed PBS after UVB testing, added culture medium again to culture in the culture incubator for $24 \mathrm{~h}$, and then used in the experiment.

\section{Cell viability estimation}

I used the principle of WST assay to estimate cell viability. I used EZ-Cytox cell viability assay kit (Itsbio, Seoul, Korea), and after inoculating $\mathrm{HaCaT}\left(3 \times 10^{3}\right.$ cells/well $)$ in 96-well plate and cultured for $24 \mathrm{~h}$, I treated $\mathrm{HaCaT}$ with geniposidic acid of each density of $5,10,20,30$, and $40 \mu \mathrm{M}$ respectively, tested $40 \mathrm{~mJ} / \mathrm{cm}^{2}$ of UVB, and then cultured for $24 \mathrm{~h}$. After I added $10 \mu \mathrm{L}$ of EZ-Cytox cell viability assay kit reagent (ItsBio) into cultured well and cultured for $1 \mathrm{~h}$, I used microplate reader (Bio-Rad, Hercules, CA, USA). I estimated the absorbance in the scale of $490 \mathrm{~nm}$, repeated each experiments three times separately, and derived average value and standard deviation of cell viability.

\section{Cell cycle analysis}

I used an equipment of BD FACS Calibur Flow Cytometer (BD Biosciences, San Jose, CA, USA). I estimated the number of cells in sub-G1, G1, S, and G2/M cell 
cycle to analyze cell cycle. After I inoculated $2 \times 10^{5}$ cells/well of HaCaT in $60 \mathrm{~mm}$ of culture dish, I cultured it for $24 \mathrm{~h}$, and then, I pretreated it with geniposidic acid for $3 \mathrm{~h}$. After testing UVB, I cultured it for $24 \mathrm{~h}$ more and obtained cultured cells, and then, I centrifuged it at $5000 \mathrm{rpm}$ with temperature at $4{ }^{\circ} \mathrm{C}$ for $5 \mathrm{~min}$ and precipitated cells. After I removed the supernatant and dissolved the cell pellet with $300 \mu \mathrm{L}$ of PBS, I slowly added $700 \mu \mathrm{L}$ of absolute ethanol (Biopure, Canada) while vortexing, and I refrigerated it with temperature at $4{ }^{\circ} \mathrm{C}$ for $3 \mathrm{~h}$ to fix cells. I added $1 \mathrm{~mL}$ of PBS, centrifuged at $5000 \mathrm{rpm}$ with temperature at $4{ }^{\circ} \mathrm{C}$ for $5 \mathrm{~min}$ to remove supernatant, dissolved the pellet with $200 \mu \mathrm{L}$ of propidium iodide (PI) staining buffer (PI $50 \mu \mathrm{g} / \mathrm{mL}$, RNase $0.1 \mu \mathrm{g} / \mathrm{mL}, 0.05 \%$ Triton X-100; Sigma Aldrich), and then settled with temperature at $37{ }^{\circ} \mathrm{C}$ for $1 \mathrm{~h}$. Afterward, I centrifuged $\mathrm{HaCaT}$ cells at $5000 \mathrm{rpm}$ with temperature at $4{ }^{\circ} \mathrm{C}$ for $5 \mathrm{~min}$ to remove supernatant and washed with PBS, and then, I dissolved the pellet with $1 \mathrm{~mL}$ of PBS and through Flow Cytometer estimated the number of cells in each cell cycle.

\section{qRT-PCR analysis}

To analyze and find out gene expression occurred within $\mathrm{HaCaT}$ by geniposidic acid quantitatively, I used qRTPCR method. I mixed $0.2 \mu \mathrm{M}$ of primers, $20 \mathrm{mM}$ of Tris/ $\mathrm{HCl}$ in a $\mathrm{pH}$ of $8.4,50 \mathrm{mM} \mathrm{KCl}, 0.8 \mathrm{mM}$ of dNTP, $3 \mathrm{mM}$ of $\mathrm{MgCl}_{2}, 0.5 \mathrm{U}$ Extaq DNA polymerase, and $1 \times$ SYBR green (Invitrogen) in PCR tube to manufacture reaction solution and used Linegene $\mathrm{K}$ (BioER, Zhejiang, China). After denaturation with temperature at $94{ }^{\circ} \mathrm{C}$ for $3 \mathrm{~min}$, I performed denaturation $\left(94^{\circ} \mathrm{C}, 30 \mathrm{~s}\right)$, annealing $\left(58{ }^{\circ} \mathrm{C}, 30 \mathrm{~s}\right)$, and polymerization $\left(72{ }^{\circ} \mathrm{C}, 30 \mathrm{~s}\right)$ for $40 \mathrm{cy}-$ cles and proceeded PCR. With melting curve, I verified the effectiveness of PCR, and by standardizing expression of $\beta$-actin, I performed the comparative analysis for each gene expression, and the primer used in the experiment is shown as Table 1.

\section{DPPH radical scavenging activity assay}

I injected the geniposidic acid diluent of each density into 96-well plate, added $50 \mu \mathrm{L}$ of $0.2 \mathrm{mM}$ of 1,1 - diphenyl-2-picrylhydrazyl (DPPH), and settled it for $30 \mathrm{~min}$. Using a microplate reader (Bio-Rad), I estimated the absorbance in the scale of $514 \mathrm{~nm}$ and repeated this estimation three times. I derived the average value and standard deviation of absorbance.

\section{$\mathrm{ABTS}^{+}$radical scavenging assay}

I mixed 7.4 $\mathrm{nm}$ of 2,2-azino-bis-3-ethylbenzthiazoline-6sulfonic acid (ABTS) and $2.6 \mathrm{mM}$ of potassium persulfate in the final density, reacted in dark room at room temperature for $12 \mathrm{~h}$, and formed $\mathrm{ABTS}^{+}$, and then, I made the value of the absorbance to be $0.706( \pm 0.01)$ in the scale of $732 \mathrm{~nm}$. After adding $100 \mu \mathrm{L}$ of $\mathrm{ABTS}^{+}$into $100 \mu \mathrm{L}$ geniposidic acid in 96-well plate and neglecting for $7 \mathrm{~min}$, I estimated the absorbance in the scale of $732 \mathrm{~nm}$. I repeated this estimation three times and derived the average value and standard deviation of the absorbance.

\section{Caspase- 3 activity}

Caspase-3 which induces apoptosis is affiliated with cysteine proteinase family, and I used Apoalert caspase-3 colorimetric assay kit (Clontech, Mountain View, CA, USA) as method to estimate pNA (p-nitroanilide) action using its character to decompose Ac-DEVD-pNA ( $N$-acetylAsp-Glu-Val-Asp p-nitroanilide) which is a substrate complex. I separated the cells treated by sample from culture dish, centrifuged it at $1500 \mathrm{rpm}$ for $5 \mathrm{~min}$, and added cold cell lysis buffer into cell pellet whose culture medium was removed, and then, I settled it under the condition of the ice for $10 \mathrm{~min}$ and centrifuged it at $15000 \mathrm{rpm}$ with temperature at $4{ }^{\circ} \mathrm{C}$ for $3 \mathrm{~min}$ to separate supernatant only. With regard to the separated supernatant, I used bradford assay to quantify only total $50 \mu \mathrm{g}$ of protein and apply to caspase-3 activity reaction. I put suspension which I finished protein quantification into 96-well plate, added reaction buffer, and cultured it with temperature at $37^{\circ} \mathrm{C}$ for $30 \mathrm{~min}$. Then, I added caspase- 3 substrate, cultured with temperature at $37{ }^{\circ} \mathrm{C}$ for $1 \mathrm{~h}$, and used microplate reader (Bio-Rad) to estimate the absorbance in the scale of $405 \mathrm{~nm}$.

Table 1 List of primers

\begin{tabular}{lll}
\hline Gene & Forward primer & Reverse primer \\
\hline$\beta$-actin & GGATTCCTATGTGGGCGACGA & CGCTCGGTGAGGATCTTCATG \\
P21 & GTCCAGCGACCTTCCTCATCCA & CCATAGCCTCTACTGCCACCATC \\
GADD45a & GAGAGCAGAAGACCGAAAGGA & CACAACACCACGTATCGGG \\
SOD1 & GGGAGATGGCCCAACTACTG & CCAGTTGACATGCAACCGTT \\
SOD2 & GCCCTGGAACCTCACATCAA & GGTACTTCTCCTCGGTGACGTT \\
PCNA & TAACAGTTCCTGCATGGGCGGC & CGTGCAAATCACCAGAAGGC \\
XPC & AGCAGCTTCCCACCTGTTC & GTGGGTGCCCCTCTAGTG \\
\hline
\end{tabular}


Comet assay (single-cell gel electrophoresis)

I used CometAssay ${ }^{\circ}$ Reagent Kits (Trevigen, Gaithesburg, MD, USA) and melted LMAgarose (low melting agarose) completely for $5 \mathrm{~min}$, and then, I covered it with cab, cooled in water bath whose temperature was at $37{ }^{\circ} \mathrm{C}$ for $20 \mathrm{~min}$, and mixed $1 \times 10^{5}$ cells $/ \mathrm{mL}$ of cell with melted LMAgarose (at $37{ }^{\circ} \mathrm{C}$ ) at the ratio of 1 to $10(\mathrm{v} / \mathrm{v})$. Afterward, I poured $50 \mu \mathrm{L}$ of mixed liquor onto Comet slide and kept in slide in the refrigerator with temperature at $4{ }^{\circ} \mathrm{C}$ for $10 \mathrm{~min}$, and then, I immersed the slide in alkaline solution at room temperature for $20 \mathrm{~min}$. After I immersed the slide in alkaline electrophoresis solution and covered, I electrophoresed it with voltages at $21 \mathrm{~V}$ for $30 \mathrm{~min}$, and after finishing electrophoresis, I immersed it twice in distilled water for $4 \mathrm{~min}$ to remove electrophoresis solution and immersed in $70 \%$ ethanol for $5 \mathrm{~min}$. I dried it with temperature at $37^{\circ} \mathrm{C}$, put dried agarose gel into $100 \mu \mathrm{L}$ of SYBR ${ }^{\oplus}$ gold nuclei acid gel stain (Invitrogen), and dyed it in the dark room for $30 \mathrm{~min}$. I rinsed it with water simply to remove dyeing reagent and observed agarose gel which I dried it completely with temperature at $37{ }^{\circ} \mathrm{C}$ through fluorescence microscope.

\section{MDA assay}

I used colorimetric method to estimate malondialdehyde (MDA) level and used Lipid Peroxidation (MDA) Assay Kit (Abcam, Cambridge, UK). First, I inoculated $1 \times 10^{7}$ cells/well of $\mathrm{HaCaT}$ in 6-well plate and pretreated it with reagent, and then, I tested the UV and cultured it for $48 \mathrm{~h}$. I used a microplate reader (Bio-Rad) to estimate in the scale of $586 \mathrm{~nm}$ and used the principle that oxidated lipid (MDA) reacts with TBA (thiobarbituric acid) within kit and detects through colorimetric method.

\section{Statistical process}

In this research, I performed every experiment more than three times separately under the same condition and obtained experimental result, and used Student's $t$ test for each experiment and found $p$ value. When $p$ value in every experimental result is less than 0.05 , I analyzed that it is statistically significant.

\section{Results \\ Cell viability analysis}

To find out cytotoxicity which geniposidic acid influences on $\mathrm{HaCaT}$, I performed the cell viability assay. I treated the $\mathrm{HaCaT}$ keratinocytes with geniposidic acid of each density of $5,10,20,30$, and $40 \mu \mathrm{M}$ respectively. As the result of testing cytotoxicity, it did not influence on viability till $20 \mu \mathrm{M}$. When geniposidic acid was $20 \mu \mathrm{M}$, the viability was $87 \%$, and when geniposidic acid was $30 \mu \mathrm{M}$, it was $73 \%$, and when geniposidic acid was $40 \mu \mathrm{M}$, it was $66 \%$, so the cell viability appeared as decreasing (Fig. 1a). To find out whether geniposidic acid has an effect to preserve $\mathrm{HaCaT}$ keratinocytes against UVB irradiation, I pretreated the $\mathrm{HaCaT}$ keratinocytes with geniposidic acid of each density of 10, 20, and $30 \mu \mathrm{M}$ respectively and tested UVB of $40 \mathrm{~mJ} / \mathrm{cm}^{2}$ to find out changing of cell viability. As the result, when I did not treat $\mathrm{HaCaT}$ keratinocytes with geniposidic acid but tested UVB only, cell viability decreased to $72 \%$, but at the case of pretreatment with geniposidic acid of $10 \mu \mathrm{M}$, it was $75 \%$; at the case of pretreatment with $20 \mu \mathrm{M}$, it was $81 \%$; at the case of pretreatment with $30 \mu \mathrm{M}$, it was $87 \%$, and $88 \%$ at $40 \mu \mathrm{M}$ pretreatment. Therefore, I found out that cell viability of $\mathrm{HaCaT}$ keratinocytes restores dependently on density of geniposidic acid (Fig. 1b).

\section{Analysis of cell cycle distribution and apoptotic cell death} To find out through what mechanism geniposidic acid works with regard to the effect to preserve against cytotoxicity caused by UVB dependently on density, I performed cell cycle analysis. I dyed $\mathrm{HaCaT}$ with PI and used flow cytometer for untreated control group, treatment group with UVB of $40 \mathrm{~mJ} / \mathrm{cm}^{2}$, and treatment group with both UVB $40 \mathrm{~mJ} / \mathrm{cm}^{2}$ and geniposidic acid of each density of 10,20 , and $30 \mu \mathrm{M}$ respectively to estimate cell cycle progress. As the result of examining changing of cell cycle distribution, it was shown as Fig. 2a
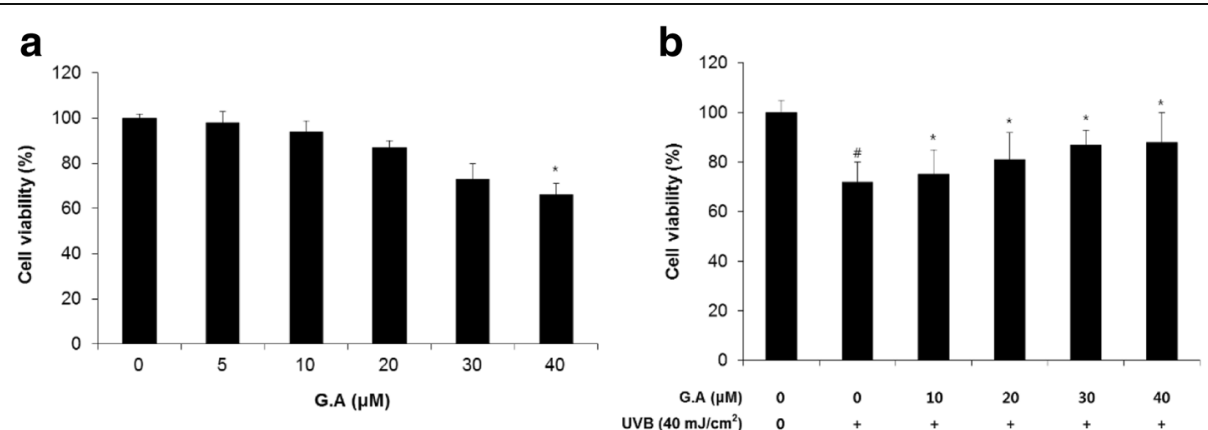

Fig. 1 Cell viability on geniposidic acid in HaCaT keratinocytes. a Cell cytotoxicity of geniposidic acid on HaCaT keratinocytes. b Protective effect of geniposidic acid on UVB-induced damages in HaCaT cells ( ${ }^{*} p<0.05$ ) 


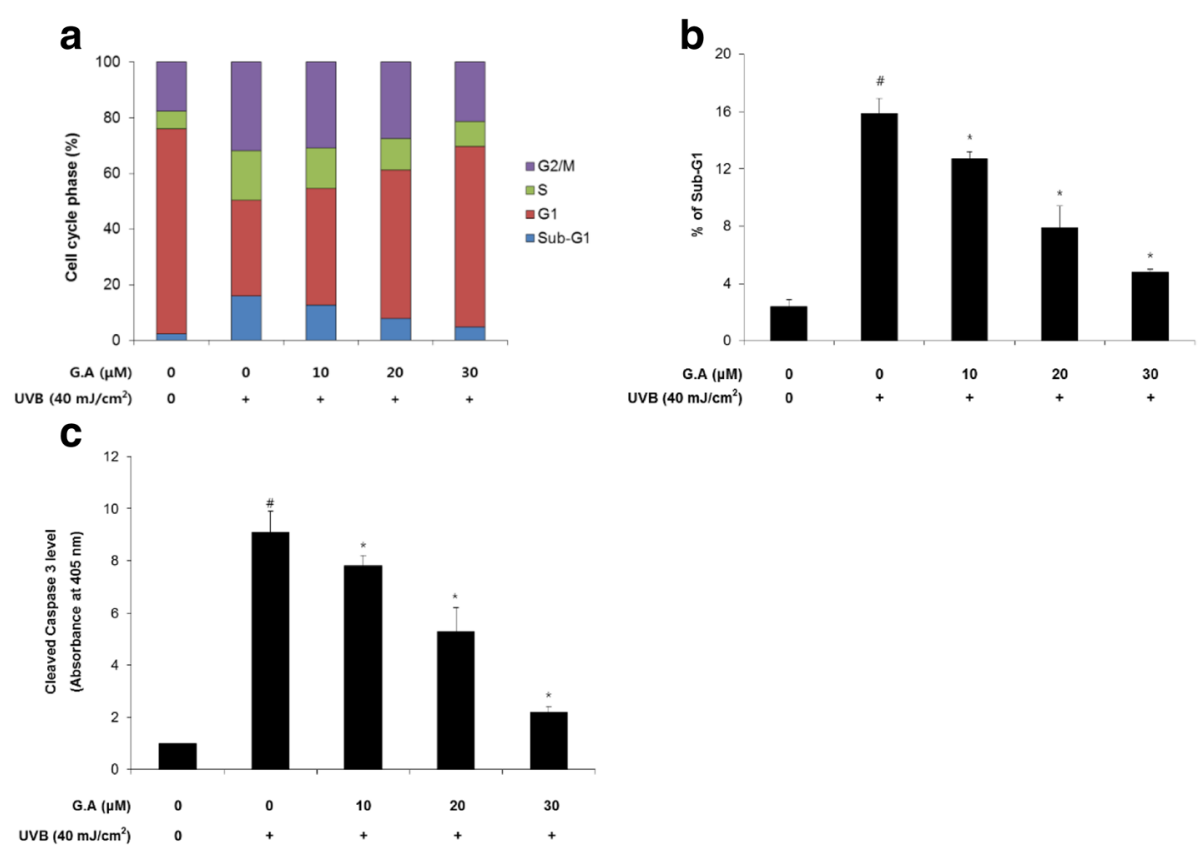

Fig. 2 Cell cycle and sub-G1 analysis of geniposidic acid-treated HaCaT, damaged by UVB. a Cell cycle distribution of geniposidic acid-treated HaCaT, damaged by UVB. $\mathbf{b}$ Effect of geniposidic acid on UVB-induced sub-G1 population in HaCaT. c Effect of geniposidic acid on UVB-induced cleaved caspase-3 level in $\mathrm{HaCaT}\left({ }^{*} p<0.05\right)$

in which G1 value of treatment group with UVB of $40 \mathrm{~mJ} / \mathrm{cm}^{2}$ reduces 39.2 to $34.4 \%$ while $\mathrm{G} 1$ value of control group is $73.6 \%$, so it was shown that UVB causes G1 cell cycle arrest to suppress cell growth. When with geniposidic acid of each density of 10,20 , and $30 \mu \mathrm{M}$, I treated the treatment group with UVB of $40 \mathrm{~mJ} / \mathrm{cm}^{2}$ respectively, $\mathrm{G} 1$ value increased to $41.8,53.4$, and $64.9 \%$ individually. It is considered that G1 cell cycle arrest caused by UVB is suppressed by geniposidic acid (Fig. 2a).

I found out the effect of geniposidic acid on sub-G1 of $\mathrm{HaCaT}$ irradiated with UVB. Sub-G1 value of untreated control group increased from 2.4 to $15.9 \%$ by UVB; however, it was shown that the value decreases dependently on density of geniposidic acid, so at the case of treatment with $10 \mu \mathrm{M}$ of geniposidic acid, the value was $12.7 \%$; at the case of $20 \mu \mathrm{M}$, it was $7.9 \%$; and at the case of $30 \mu \mathrm{M}$, it was $4.8 \%$. It is considered that UVB causes increasement in cell population of sub-G1 and apoptosis increases, but geniposidic acid reduces sub-G1 similar to control group to suppress apoptosis (Fig. 2b).

As the result of searching relative value of cleaved caspase- 3 of $\mathrm{HaCaT}$ cell treated with geniposidic acid, the amount of cleaved caspase- 3 increased to 9.1 at the case of treatment with UVB $40 \mathrm{~mJ} / \mathrm{cm}^{2}$, when the amount of cleaved caspase- 3 of untreated control group was 1. It is found that UVB induces apoptosis, and when with geniposidic acid of each density of 10, 20, and $30 \mu \mathrm{M}$, I treated the treatment group with UVB $40 \mathrm{~mJ} /$ $\mathrm{cm}^{2}$ respectively, the amount of cleaved caspase- 3 decreased to $7.8,5.3$, and 2.2 individually. It is considered that UVB causes an increase in the amount of cleaved caspase- 3 and apoptosis increases, but geniposidic acid suppresses apoptosis, and so geniposidic acid has an effect to preserve cells (Fig. 2c).

\section{Incitation of DNA damage protection and repair mechanism}

I found out cell preservation effect of geniposidic acid on DNA damage through comet assay. As the result about changing of DNA damage in $\mathrm{HaCaT}$ which was treated with UVB and again with geniposidic acid, DNA tail increased to $67 \%$ after treating with UVB of $40 \mathrm{~mJ} / \mathrm{cm}^{2}$, while it was $3 \%$ at the case of untreated control group of $\mathrm{HaCaT}$ cells. It is considered that UVB causes DNA damage, and when with geniposidic acid of each density of 10 , 20 , and $30 \mu \mathrm{M}$, I treated the treatment group with UVB $40 \mathrm{~mJ} / \mathrm{cm}^{2}$ respectively, DNA tail decreased to 61,44 , and $19 \%$ individually. It is considered that UVB causes increase of tailed DNA and DNA damage, but geniposidic acid reduces it to preserve DNA, and that geniposidic acid has an effect to preserve cells (Fig. 3a). To find out what effects on damaged DNA caused by UV geniposidic acid have, I studied changing of CPD, and the result showed that CPD increases to $100 \%$ after treating with UVB $40 \mathrm{~mJ} / \mathrm{cm}^{2}$, while it is $1 \%$ at the case of untreated control group of $\mathrm{HaCaT}$. It is considered that UVB causes DNA damage and CPD increases, and when with geniposidic acid of each density of 

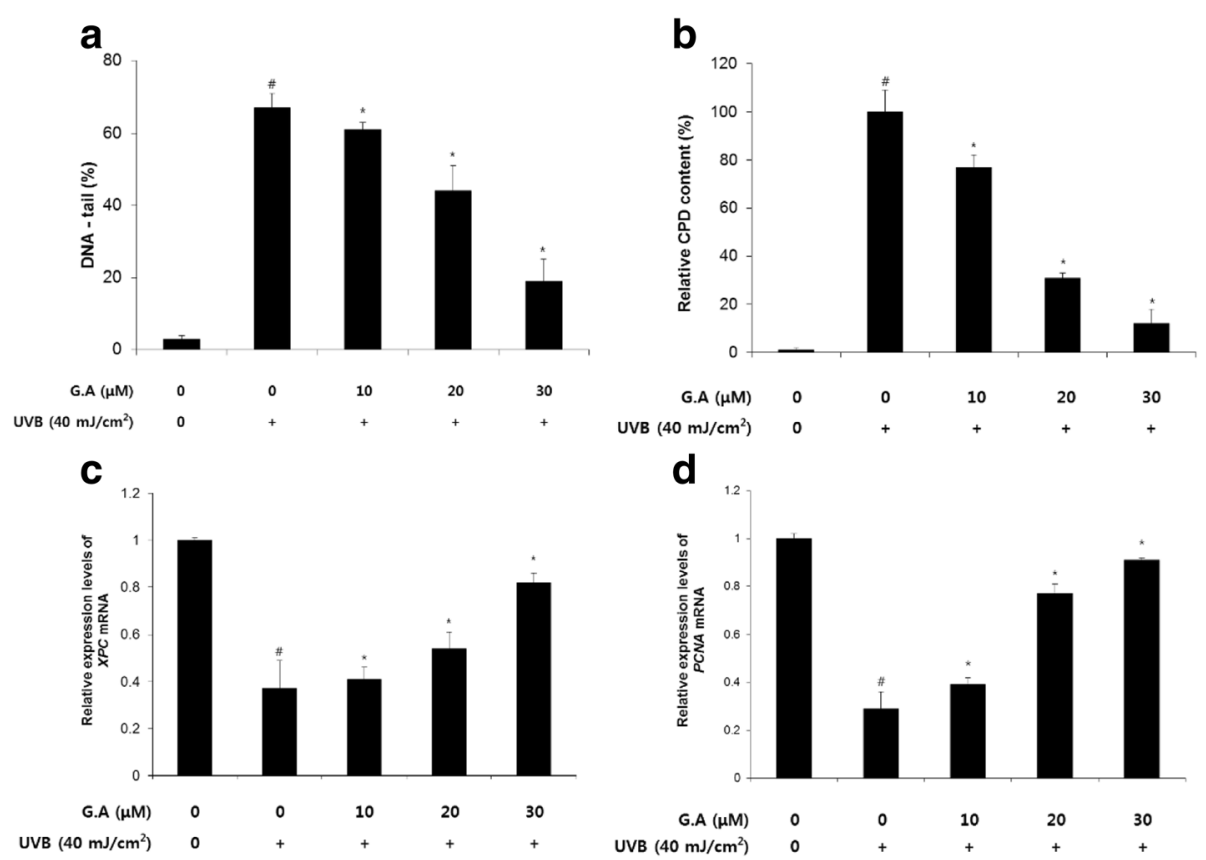

Fig. 3 Analysis of DNA damage protection activity of geniposidic acid on UVB-irradiated HaCaT. a Effect of geniposidic acid on UVB-induced DNA damage in HaCaT. $\mathbf{b}$ Effect of geniposidic acid on UVB-induced CPD formation in HaCaT. c Effect of geniposidic acid on UVB-induced XPC gene expression in HaCaT. $\mathbf{d}$ Effect of geniposidic acid on UVB-induced PCNA gene expression in $\mathrm{HaCaT}\left({ }^{*} p<0.05\right)$

10,20 , and $30 \mu \mathrm{M}$, I treated the treatment group with UVB $40 \mathrm{~mJ} / \mathrm{cm}^{2}$ respectively, CPD decreased to 77,31 , and $12 \%$ individually. It is considered that UVB causes increasement in CPD and DNA damage increases, but geniposidic acid preserves cells, and that geniposidic acid has an effect to preserve cells (Fig. 3b). To examine changing of XPC expression, the DNA repair gene within $\mathrm{HaCaT}$, caused by geniposidic acid, I performed qRT-PCR. XPC expression decreased to 0.37 at the case of treatment with $40 \mathrm{~mJ} / \mathrm{cm}^{2}$ of UVB as compared with the value of untreated control group which was 1 . It is expected that UVB causes DNA damage, and I found that when with geniposidic acid of each density of 10,20 , and $30 \mu \mathrm{M}$, I treated the treatment group with UVB of $40 \mathrm{~mJ} / \mathrm{cm}^{2}$ respectively, XPC expression which was decreased due to UVB irradiation increased to $0.41,0.54$, and 0.82 individually as dose-dependent manner of geniposidic acid (Fig. 3c). It is considered that geniposidic acid has an effect on DNA damage caused by UVB to protect DNA. PCNA is a nucleoprotein of $36 \mathrm{kDa}$ which is called as cyclin, and it increases all over the cell cycle from the end of G1 to S period. This is a secondary protein of DNA polymerase delta, and it has been reported that it has an important role in the beginning of cell proliferation (Jung and Jeong 1997). To examine changing of expression of PCNA, the DNA repair gene within $\mathrm{HaCaT}$, I performed qRT-PCR. PCNA expression decreased to 0.29 at the case of treatment with UVB of $40 \mathrm{~mJ} / \mathrm{cm}^{2}$ as compared with the value of untreated control group which was 1 . It is expected that UVB causes DNA damage, and I found that when with geniposidic acid of each density of 10,20 , and $30 \mu \mathrm{M}$ with irradiation of UVB at $40 \mathrm{~mJ} / \mathrm{cm}^{2}$ respectively, the expression which has decreased by UVB increased significantly to $0.39,0.77$, and 0.91 individually and dependently on density (Fig. 3d). It is considered that geniposidic acid has an effect on DNA damage repair caused by UVB.

\section{Anti-oxidant properties analysis}

DPPH is a water-soluble substance which has chemically stable free radical and has its maximum absorbance at the scale of $515-520 \mathrm{~nm}$. When it meets with substances which show anti-oxidant action, it gives an electron and its radical becomes extinct to change its color. DPPH radical scavenging ability is a method to estimate the degree of anti-oxidation through the course of reacting with anti-oxidant substance to accept hydrogen atom and suppress oxidation. As the result of examining the anti-oxidation effect of geniposidic acid, I found that when I treated it with geniposidic acid of each density of $10,20,30$, and $40 \mu \mathrm{M}$, its anti-oxidation effect was respectively about $18,25,65$, and $80 \%$ dependently on density and similar to L-ascorbic acid, the positive control group (Fig. 4a).

ABTS reacts with potassium persulfate to form $\mathrm{ABTS}^{+}$ of blue/green. It is the method to evaluate anti-oxidation action through analysis on the degree of decoloration by anti-oxidant. As the result of examining the antioxidation effect of geniposidic acid, I found that when I 

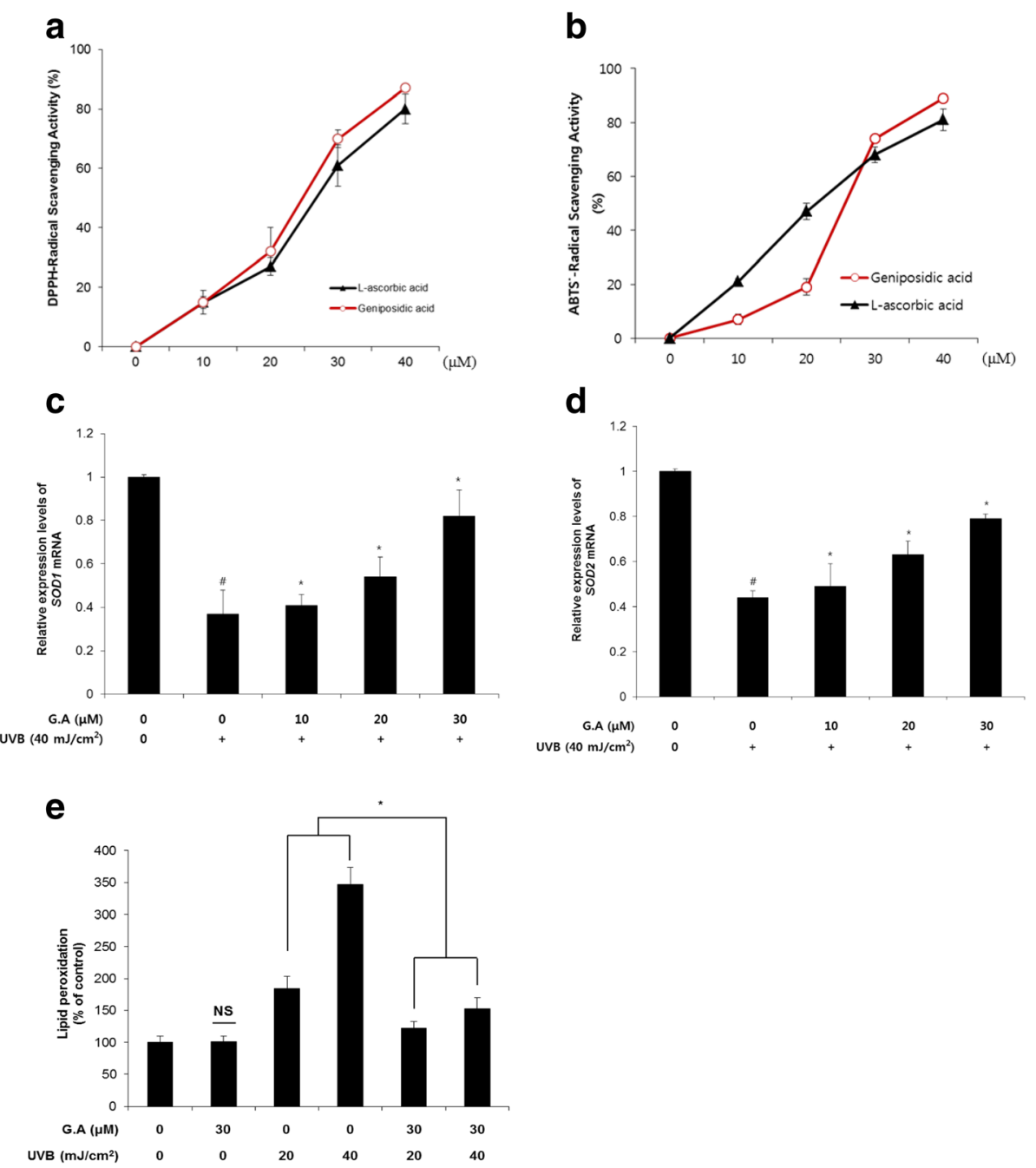

Fig. 4 Anti-oxidant effect of geniposidic acid on HaCaT. a Effect of geniposidic acid on DPPH radical scavenging activity. b Effect of geniposidic acid on ABTS radical scavenging activity. c Effect of geniposidic acid on UVB-induced SOD1 gene expression in HaCaT. $\mathbf{d}$ Effect of geniposidic acid on UVB-induced SOD2 gene expression in HaCaT. e Effect of geniposidic acid on UVB-induced lipid peroxidation in $\left.\mathrm{HaCaT}^{*} p<0.05\right)$

treated it with geniposidic acid of each density of 10, 20, 30 , and $40 \mu \mathrm{M}$ respectively, the anti-oxidation effect was about $8,20,80$, and $95 \%$ dependently on density and similar to L-ascorbic acid, the positive control group (Fig. 4b). Within the human body, there is a representative anti-oxidation enzyme, SOD which can protect itself against damages by reactive oxygen and has a role to transform the reactive oxygen radical $\left(\mathrm{O}_{2}^{-}\right)$into $\mathrm{H}_{2} \mathrm{O}$ and $\mathrm{H}_{2} \mathrm{O}_{2}$ to reduce the density of reactive oxygen in the body (McCord and Fridovich 1969; Fridovich 1995). Among this SOD enzyme, there are SOD1 existing in the cytoplasm, SOD2 existing in mitochondria, and SOD3 existing in the outside of cell (Huang et al. 1999), and SOD1 is the representative anti-oxidation enzyme of all SOD enzymes, contains cytoplasm, and has a role to decrease ROS with regard to all tissues in which oxygen exists (Crapo et al. 1992).
To examine what effects on changing of SOD1 expression geniposidic acid have, I performed qRT-PCR. It was shown that while $S O D 1$ expression in $\mathrm{HaCaT}$ decreases 0.37 times by irradiation with UVB of $40 \mathrm{~mJ} / \mathrm{cm}^{2}$, the amount of expression increases dependently on density of geniposidic acid, so at the case of treatment with $10 \mu \mathrm{M}$, the amount increases 0.41 times; at the case of $20 \mu \mathrm{M}$, it increases 0.54 times; and at the case of $30 \mu \mathrm{M}$, it increases 0.82 times (Fig. 4c). It is considered that geniposidic acid induces increase in $S O D 1$ expression to reduce reactive oxygen and suppress cellular senescence. To examine what effects on changing of mRNA expression of SOD2 which is anti-oxidant enzyme existing within mitochondria geniposidic acid have, I used qRTPCR. It was shown that while SOD2 expression in $\mathrm{HaCaT}$ decreases 0.44 times by treatment with UVB of $40 \mathrm{~mJ} / \mathrm{cm}^{2}$, the amount of expression increases 
dependently on density of geniposidic acid, so at the case of treatment with $10 \mu \mathrm{M}$, the amount increases 0.49 times; at the case of $20 \mu \mathrm{M}$, it increases 0.63 times; and at the case of $30 \mu \mathrm{M}$, it increases 0.79 times (Fig. $4 \mathrm{~d}$ ). Next, I searched what effects on changing of lipid peroxidation geniposidic acid have. When I treated it with UVB of $20 \mathrm{~mJ} / \mathrm{cm}^{2}$, lipid peroxidation increased to $184 \%$, and at the case of treatment with UVB of $40 \mathrm{~mJ} / \mathrm{cm}^{2}$, it increased to $347 \%$. It is considered that UVB causes oxidative stress and lipid peroxidation increases. With geniposidic acid of $30 \mu \mathrm{M}$, I treated both treatment group with UVB 20 and $40 \mathrm{~mJ} / \mathrm{cm}^{2}$ respectively, and I found that lipid peroxidation decreases to $122 \%$ at the case of treatment group with UVB $20 \mathrm{~mJ} / \mathrm{cm}^{2}$ and decreases to $153 \%$ at the case of treatment group with UVB $40 \mathrm{~mJ} / \mathrm{cm}^{2}$ (Fig. 4e).

\section{Discussion}

\section{Cell preservation effects of geniposidic acid on $\mathrm{HaCaT}$ against UVB}

DNA damage caused by UV results in increase in $p 53$ gene expression, and $p 53$, the transcriptional factor, controls more than 100 genes which are induced by DNA damage (Latonen et al. 2001; Jin et al. 2000). p53 is a representative transcriptional factor which induces cell cycle arrest, suppression of cell growth, and promotion of apoptosis (Yoon 2013), and cell cycle arrest occurs in G1/S or G2 period of cell cycle depending on the condition of p53 action. Also, when UV causes DNA damage, $p 53$ induces $p 21$ gene expression, and expressed $p 21$ causes cell cycle arrest through activity of cyclindependent kinase (CDK) to hinder cell growth (Smits and Medema 2001; Yoon 2013; Gewirtz et al. 2008). According to recent papers, it has been reported that p53 expression is suppressed in order to stop the promotion of senescence of normal tissue in adult mouse as the result of analysis on p53 mouse model (Gannon et al. 2011).

In this research, I found out what effects on cell damage caused by UVB geniposidic acid have, when I treated human keratinocytes with geniposidic acid. When I pretreated $\mathrm{HaCaT}$ keratinocytes with geniposidic acid of each density of 10,20 , and $30 \mu \mathrm{M}$ respectively and tested with UVB of $40 \mathrm{~mJ} / \mathrm{cm}^{2}$, I found that the cell viability restores dependently on density (Fig. 1b). I could know that geniposidic acid increases in the number of cells during G1 period although UVB causes G1 cell cycle arrest (Fig. 2a), and I could find that sub-G1 decreases as the density of geniposidic acid increases (Fig. 2b). Therefore, it is considered that geniposidic acid has effects on cell damage caused by UVB to suppress apoptosis and preserve cells.

Caspase-3 amplifies initial signal to caspase- 8 and caspase-9, and it is known that it is directly related with apoptosis (Kennedy et al. 2001), and it has been recognized that it induces DNA fragmentation and pycnosis to cause apoptosis (Soldani and Scovassi 2002).

As the result of examining changing of caspase- 3 action in this research, the amount of cleaved caspase-3 expression increased by UVB, but I could find that the amount of cleaved caspase-3 expression decreases by treatment with geniposidic acid of each density (Fig. 2c). Therefore, it is judged that geniposidic acid has effects on cell damage caused by UVB to suppress apoptosis and preserve cells.

\section{DNA repair effect of geniposidic acid on $\mathrm{HaCaT}$ against UVB}

As the result of examining cell preservation effects of geniposidic acid on DNA damage, I could know that UVB increases in tailed DNA, but it reduces by treatment with geniposidic acid as indicated concentration (Fig. 3a). Also, I studied changing of CPD formation to find what effects on damaged DNA by UVB have, and I could know that UVB causes increase in CPD and DNA damage and find that CPD reduces as the density of geniposidic acid increases (Fig. 3b). Therefore, it is judged that geniposidic acid has effects to protect DNA and preserve cells. Finally, it is considered that geniposidic acid would have important roles to control expression of hypostatic genes of p53 caused by UVB, to normalize cell cycle, and to suppress dermal cellular senescence.

P53 is activated by UV, oxidative stress or DNA damage, etc. (Miliani de Marval and Zhang 2011; Lee et al. 2016), and it controls expression of genes related with various senescence such as $p 21$ (cyclin-dependent kinase inhibitor 1A), 14-3- $\sigma$ and GADD45a (growth arrest and DNA-damage-inducible, alpha) which are subordinate targets (Brown et al. 1997; Kortlever et al. 2006). P21 arrests cell cycle and hinders cell growth through the activity of CDK (Smits and Medema 2001; Gewirtz et al. 2008). GADD45a controls superordinate stage of transmission system of $\mathrm{Cdc} 2$ protein kinase, PCNA, p21Waf1/Cip1 protein, core histone protein, MTK/ MEKK4, and JNK/SAPK, and it is concerned with suppression of cell cycle and DNA repair through protein and signal transmission system within various cells, and it has an important role to prevent DNA damage. XPC is known that it reacts first for recognition of damaged DNA. As the result of examining changing of expression of $X P C$ which is one of DNA repair genes, I found that $X P C$ expression significantly increases dependently on density of geniposidic acid while it reduces by UVB (Fig. 3c). Therefore, it is considered that geniposidic acid has an effect on DNA damage to repair DNA. It has been reported that PCNA is a nucleoprotein of $36 \mathrm{kDa}$ which is called as cyclin and increases all over the cell cycle from the end of G1 to S period, and it is also secondary protein of DNA polymerase delta and has an 
important role in the beginning of cell proliferation (Jung and Jeong 1997). As the result of examining changing of expression of PCNA, the DNA repair gene, I could know that $P C N A$ expression increases dependently on density of geniposidic acid while it reduces by UVB (Fig. 3d). Therefore, it is judged that geniposidic acid has an effect on damaged DNA by UVB to repair DNA.

\section{Anti-oxidation effects of geniposidic acid on $\mathrm{HaCaT}$ against UVB}

ROS which has been increased within cells causes intracellular damages such as DNA damage, mitochondria damage, protein oxidation, and disorder of energy metabolism, and intracellular damage caused by oxidative stress can result in cell cycle arrest, cellular senescence, and apoptosis (Cerella et al. 2009).

As shown in Fig. 4a, b, with regard to anti-oxidation effects, I found that geniposidic acid has an antioxidation effect similar to L-ascorbic acid which is known as anti-oxidation standard substance through $\mathrm{DPPH}$ assay and $\mathrm{ABTS}^{+}$assay with treatment of geniposidic acid. Its function to remove reactive oxygen works effectively at normal time to continue homeostasis in our human body, but it can have harmful effects on cells when it loses its balance to incline toward promotion of oxidation, and this harmful activity is called as oxidative stress. To examine what effects on changing of SOD1 and SOD2 expression geniposidic acid have, I performed qRT-PCR in this research. As shown in Fig. 4c, d, I could know that the amount of SOD1 and SOD2 expression increases dependently on density of geniposidic acid while it decreases by UVB which is one of oxidative stress. Therefore, it is considered that geniposidic acid increases SOD1 and SOD2 expression to reduce reactive oxygen and suppress cellular senescence, and it is judged that geniposidic acid has an anti-oxidation effect. To examine anti-oxidation effects of geniposidic acid, I used lipid peroxidation which is an indicator to estimate oxidative stress and observed its changing. As the result of this experiment, I found that lipid peroxidation reduces at the case of treatment with geniposidic acid of $30 \mu \mathrm{M}$ while the oxidative stress caused by UVB increases in lipid peroxidation (Fig. 4e). It is considered that with particular density of $30 \mu \mathrm{M}$, geniposidic acid has an anti-oxidation effect.

Finally, it is considered that the study on the effectiveness of geniposidic acid on the mechanism controlling expression of factors which promote senescence through damage of dermal cells caused by UVB can help evaluating whether geniposidic acid is a natural functional cosmetic material which is helpful to preserve dermal cells and delay their senescence against UVB.

\section{Conclusions}

This paper used a natural compound, geniposidic acid, affiliated with iridoid glycoside which is known as effective for anti-oxidation, anti-inflammation, anticancer, anti-stress, and improvement of immune system to study about such effects as cell preservation, antioxidation, and DNA repair on human keratinocyte damaged by UVB.

I found that at the case of testing $\mathrm{HaCaT}$ with UVB of $40 \mathrm{~mJ} / \mathrm{cm}^{2}$, cell viability reduces to $26 \%$ and cell proliferation is suppressed, but at the case of testing with the same UVB of $40 \mathrm{~mJ} / \mathrm{cm}^{2}$ after pretreating with geniposidic acid of each density of 10,20 , and $30 \mu \mathrm{M}$ respectively for $3 \mathrm{~h}$, the cell viability restores dependently on density (Fig. 1b).

I performed cell cycle analysis and found that geniposidic acid has an effect to increase in G1 to prevent G1 cell cycle arrest caused by UVB (Fig. 2a) and that UVB causes increasement in cell population of sub-G1 and apoptosis increases, but sub-G1 reduces as the density of geniposidic acid increases. From these results, I could know that geniposidic acid has effects to suppress apoptosis and preserve cells (Fig. 2b). As the result of examining changing of caspase- 3 action, I found that the amount of cleaved caspase- 3 decreases to 7.8, 5.3, and 2.2 respectively when with geniposidic acid of each density of 10,20 , and $30 \mu \mathrm{M}$, I treated treatment group with UVB of $40 \mathrm{~mJ} / \mathrm{cm}^{2}$ individually. I could know that UVB causes increasement in the amount of cleaved caspase-3 expression and apoptosis increases, and it decreases at the case of treatment with geniposidic acid of each density, and so geniposidic acid has effects to suppress apoptosis and preserve cells (Fig. 2c). Through single-cell gel electrophoresis, I found cell preservation effect of geniposidic acid on DNA damage. I found that when with geniposidic acid of each density of 10,20 , and $30 \mu \mathrm{M}$, I treated treatment group with UVB of $40 \mathrm{~mJ} / \mathrm{cm}^{2}$ respectively, DNA tail decreases to 61,44 , and $19 \%$ individually, and I could know that UVB causes increasement in DNA tail and DNA damage increases, and it decreases as I treated it with geniposidic acid of each density, and so geniposidic acid has a cell preservation effect (Fig. 3a). To find out what effects on damaged DNA by UVB geniposidic acid have, I studied changing of CPD. As the result of this experiment, I found that CPD increases to $100 \%$ when I treated $\mathrm{HaCaT}$ with UVB of $40 \mathrm{~mJ} / \mathrm{cm}^{2}$, and at the case of treatment with geniposidic acid of each density of 10,20 , and $30 \mu \mathrm{M}$ respectively, CPD decreases to 77,31 , and $12 \%$ individually. I found that UVB causes increasement in CPD and DNA damage increases, and I could know that CPD decreases 
at the case of treatment with geniposidic acid of each density, and so geniposidic acid has effects to protect DNA and preserve cells (Fig. 3b).

By using qRT-PCR, I analyzed the effect of geniposidic acid on gene expression in $\mathrm{HaCaT}$ which was treated with UVB. I found that $X P C$, the DNA repair gene, decreases in its expression by UVB, but $X P C$ expression significantly increases dependently on density of geniposidic acid, and I could find that geniposidic acid has a DNA repair effect on DNA damage caused by UVB (Fig. 3c). I found that $P C N A$, the DNA repair gene, decreases in its expression by UVB, but PCNA expression significantly increases dependently on density of geniposidic acid, and I could find that geniposidic acid has a DNA repair effect on DNA damage caused by UVB (Fig. 3d).

To examine an anti-oxidation effect of geniposidic acid, I used DPPH radical scavenging activity. As the result of analysis, I found that when I treated it with geniposidic acid of each density of $10,20,30$ and $40 \mu \mathrm{M}$, its anti-oxidation effect appears as about 18, 25, 65, and $80 \%$ dependently on density, and so geniposidic acid has a similar anti-oxidation effect to L-ascorbic acid which is the positive control group (Fig. 4a). Also, as the result of examining the anti-oxidation effect of geniposidic acid through ABTS radical scavenging activity, I found that when I treated it with geniposidic acid of each density of $10,20,30$, and $40 \mu \mathrm{M}$ respectively, its anti-oxidation effect appears as about $8,20,80$, and $95 \%$ dependently on density, and so geniposidic acid has a similar antioxidation effect to $\mathrm{L}$-ascorbic acid which is the positive control group (Fig. 4b). To find out what effects on changing of expression of $S O D$ which is an antioxidation enzyme existing in our human body have, I performed qRT-PCR. Among SOD enzyme, I found that $S O D 1$ which exists in cytoplasm increases in its amount of expression dependently on density of geniposidic acid and that this increase in SOD1 expression reduces reactive oxygen within cytoplasm, and so geniposidic acid has an anti-oxidation effect (Fig. 4c). Also, I found that SOD2 which exists in mitochondria increases in its expression dependently on density of geniposidic acid and that increase in SOD2 expression reduces reactive oxygen within mitochondria, and so geniposidic acid has an anti-oxidation effect and cellular senescence suppression effect (Fig. 4d). Finally, I examined what effects on changing of lipid peroxidation geniposidic acid have. As the result, I found that lipid peroxidation increases in accordance with the amount of UVB but decreases as I treated it with geniposidic acid of particular density, and from this, I could find that geniposidic acid shows an effective anti-oxidative activity against the oxidative stress caused by UVB (Fig. 4e).

In this research, I found that geniposidic acid has such effects as cell preservation, anti-oxidation, and DNA repair in $\mathrm{HaCaT}$ damaged by UVB and I assure that this result proves sufficient value of geniposidic acid as a natural cosmetic material which effectively preserves cells and delays dermal cellular senescence against damage caused by UVB.

\section{Abbreviations}

ABTS: 2,2-Azino-bis-3-ethylbenzoline-6-sulphonic acid; Ac-DEVD-pNA: N-AcetylAsp-Glu-Val-Asp p-nitroanilide; ATM: Ataxia-telangiectasia mutated; ATR: ATMand Rad3-related; CDK: Cyclin-dependent kinase; CPD: Cyclobutane pyrimidine dimer; DMEM: Dulbecco's modified Eagle's medium; DMSO: Dimethyl sulfoxide; DPPH: 1,1-Diphenyl-2-picrylhydrazyl; FACS: Fluorescence-activated cell sorting; FBS: Fetal bovine serum; G.A: Geniposidic acid; GADD45a: Growth arrest and DNA-damage-inducible, alpha; HaCaT: Human keratinocyte; LMAgarose: Low melting agarose; MDA: Malondialdehyde; P21: Cyclin-dependent kinase inhibitor 1A; PBS: Phosphate-buffered saline; PCNA: Proliferating cell nuclear antigen; PI: Propidium iodide; pNA: p-nitroanilide; qRT-PCR: Quantitative realtime polymerase chain reaction; ROS: Reactive oxygen species; SOD1: Superoxide dismutase 1; SOD2: Superoxide dismutase 2;

TBA: Thiobarbituric acid; UV: Ultraviolet; WST: Water-soluble tetrazolium salts; XPC: XPC complex subunit, DNA damage recognition, and repair factor

\section{Acknowledgements}

Not applicable

Funding

Not applicable

Availability of data and materials

Not applicable

Ethics approval and consent to participate

Not applicable

Consent for publication

Not applicable

\section{Competing interests}

The author declares no competing interests.

\section{Publisher's Note}

Springer Nature remains neutral with regard to jurisdictional claims in published maps and institutional affiliations.

Received: 8 June 2017 Accepted: 19 December 2017

Published online: 20 January 2018

\section{References}

Brown JP, Wei W, Sedivy JM. Bypass of senescence after disruption of p21CIP1/ WAF1 gene in normal diploid human fibroblasts. Science. 1997;277:831-4.

Cerella C, Coppola S, Maresca V, De Nicola M, Radogna F, Ghibelli L. Multiple mechanisms for hydrogen peroxide-induced apoptosis. Ann N Y Acad Sci. 2009;1171:559-63.

Chang YC, Tseng TH, Lee MJ, Hsu JD, Wang CJ. Induction of apoptosis by pentaacetyl geniposide in rat C6 glioma cells. Chem Biol Interact. 2002;141:243-57.

Choi YH, Seo JH, Kim JS, Heor J, Kim SK, Choi SU, et al. Inhibitory effects of the stem bark extract of Eucommia ulmoides on the proliferation of human tumor cell lines. Kor J Pharmacogn. 2003;34:308-13.

Crapo JD, Qury T, Rabouille C, Slot JW, Chang LY. Cooper, zinc superoxide dismutase is primarily a cytosolic protein human cells. Pro Natl Acad Sci U S A. 1992:89:10405-9.

Deng Y, Guan M, Xie X, Yang X, Xiang H, Li H, et al. Geniposide inhibits airway inflammation and hyperresponsiveness in a mouse model of asthma. Int Immunopharmacol. 2013;17:561-7.

Fridovich I. Superoxide radical and superoxide dismutase. Annu Rev Biochem. 1995;64:97-112.

Gannon HS, Donehower LA, Lyle S, Jones SN. Mdm2-p53 signaling regulates epidermal stem cell senescence and premature aging phenotypes in mouse skin. Dev Biol. 2011;353:1-9. 
Gewirtz DA, Holt SE, Elmore LW. Accelerated senescence: an emerging role in tumor cell response to chemotherapy and radiation. Biochem Pharmacol. 2008;76:947-57.

Guan L, Feng H, Gong D, Zhao X, Cai L, Wu Q, et al. Genipin ameliorates agerelated insulin resistance through inhibiting hepatic oxidative stress and mitochondrial dysfunction. Exp Gerontol. 2013;48:1387-94.

Hong YJ, Yang KS. Anti-inflammatory activities of crocetin derivatives from processed Gardenia jasminoides. Arch Pharm Res. 2013;36:933-40.

Hsu HY, Yang JJ, Lin SY, Lin CC. Comparisons of geniposidic acid and geniposide on antitumor and radioprotection after sublethal irradiation. Cancer Lett. 1997;113:31-7.

Huang TT, Carlson EJ, Raineri I, Grillespie AM, Kozy H, Epstein CJ. The use of transgenic and mutant mice to study oxygen free radical metabolism. Ann N Y Acad Sci. 1999;893:95-112

Jenkins G. Molecular mechanisms of skin aging. Mech Ageing Dev. 2002:123:801-10.

Jin S, Antinore MJ, Lung FD, Dong X, Zhao H, Fan F, et al. The GADD45 inhibition of Cdc2 kinase correlates with GADD45-mediated growth suppression. J Biol Chem. 2000;275:16602-8.

Jung SI, Jeong GB. P53 and PCNA protein expression on the colorectal cancer tissue. Chungbuk Med J. 1997;7:223-36.

Kennedy DO, Kojima A, Yano Y, Hasuma T, Otani S, Matsui-Yuasa I. Growth inhibitory effect of green tea extract in Ehrlich ascites tumor cells involves cytochrome c release and caspase activation. Cancer Lett. 2001;166:9-15.

Kortlever RM, Higgins PJ, Bernards R. Plasminogen activator inhibitor-1 is a critica downstream target of p53 in the induction of replicative senescence. Nat Cell Biol. 2006:8:877-84.

Kulms D, Zeise E, Pöppelmann B, Schwarz T. DNA damage, death receptor activation and reactive oxygen species contribute to ultraviolet radiationinduced apoptosis in an essential and independent way. Oncogene. 2002;21: 5844-51.

Latonen L, Taya Y, Laiho M. UV-radiation induces dose-dependent regulation of p53 response and modulates p53-HDM2 interaction in human fibroblasts. Oncogene. 2001;20:6784-93.

Lee S, Han HS, An IS, Ahn KJ. Effects of amentoflavone on anti-inflammation and cytoprotection. Asian J Beauty Cosmetol. 2016;14:201-11.

Lee YR, Noh EM, Han JH, Kim JM, Hwang JK, Hwang BM, et al. Brazilin inhibits UVB-induced MMP-1/3 expressions and secretions by suppressing the NF-KB pathway in human dermal fibroblasts. Eur J Pharmacol. 2012;674:80-6.

McCord JM, Fridovich I. The utility of superoxide dismutase in studying free radical reactions. I. Radicals generated by the interaction of sulfite, dimethyl sulfoxide and oxygen. J Biol Chem. 1969;244:6056-63.

Miliani de Marval PL, Zhang Y. The RP-Mdm2-p53 pathway and tumorigenesis. Oncotarget. 2011;2:234-8.

Park SD, Kim GW. Experimental studies of eucommiae cortex according to processing. The Journal of Dong Guk Oriental Medicine. 1992;1:81-107.

Smits VA, Medema RH. Checking out the G(2)/M transition. Biochim Biophys Acta. 2001;1519:1-12.

Soldani C, Scovassi Al. Poly(ADP-ribose) polymerase-1 cleavage during apoptosis: an update. Apoptosis. 2002;7:321-8.

Yoon YM. Gene expression profiling in protection mechanism of silibinin against damage to human dermal fibroblasts caused by UVB. Asian J Beauty Cosmetol. 2013;11:93-102.

\section{Submit your next manuscript to BioMed Central and we will help you at every step:}

- We accept pre-submission inquiries

- Our selector tool helps you to find the most relevant journal

- We provide round the clock customer support

- Convenient online submission

- Thorough peer review

- Inclusion in PubMed and all major indexing services

- Maximum visibility for your research

Submit your manuscript at www.biomedcentral.com/submit

) Biomed Central 